\title{
Zaposlovanje vrhunskih športnikov v javni upravi na preizkušnji
}

\author{
UDK: 331.5:796.071.2:35
}

Darko Repenšek

Ministrstvo za šolstvo in šport

darko.repensek@gov.si

\section{IZVLEČEK}

Med vsebine ter strokovne in razvojne naloge, ki predstavljajo obstoječo podporo države športnikom sodi tudi zaposlovanje vrhunskih športnikov $\mathbf{v}$ državni upravi. Zaposlovanje je urejeno s Sporazumom o zaposlovanju vrhunskih športnikov in trenerjev v Ministrstvu za obrambo - Slovenski vojski, Ministrstvu za notranje zadeve - Policiji in Ministrstvu za finance - Carinski upravi, ki so ga ministri resorjev, ki zaposlujejo športnike in trenerje, minister za šolstvo in šport ter predsednik Olimpijskega komiteja podpisali maja leta 1996, ga novelirali leta 2007 in z aneksom dopolnili leta 2009. Na tak način je v letu 2011 v slovenski državni upravi zaposlenih 116 športnikov in trenerjev. Glede na trenutne gospodarske razmere $v$ državi, ko se kot eden od ukrepov za stabiliziranje razmer zahteva zmanjšanje števila zaposlenih $v$ javni upravi, je tudi navedeni sporazum na veliki preizkušnji. Članek ob pomenu vrhunskega športa za državo predstavlja pravne dileme in težave pri dosedanji realizaciji sporazuma in skozi proučevanje zaposlovanja vrhunskih športnikov $v$ državni upravi nakaže potrebne rešitve, ki bi nedvomno dobremu ukrepu podpore države vrhunskemu športu dal stabilno in trajno sistemsko rešitev, ki ne bi bila odvisna od volje aktualne vlade ali ekonomskih razmer $v$ državi. To je korektna opredelitev materije $v$ Zakon $\circ$ javnih uslužbencih in posledično opredelitev števila delovnih mest v Kadrovskem načrtu Vlade Republike Slovenije.

Ključne besede: šport, vrhunski športniki, zaposlovanje vrhunskih sportnikov v javni upravi

JEL: M59

\section{Uvod}

Šport lahko razumemo kot družbeni, ekonomski in medijski fenomen. Šport posega $v$ vse pore družbenega življenja in vključuje posameznike, 
ožje in širše družbene skupine ter različne sloje prebivalstva. Če povzamemo opredelitev športa, kot je zapisana $\vee$ Nacionalnem programu športa ${ }^{1}$ (2000): „Šport je pomembna dejavnost družbe, njene dinamike in del splošne kulture, ki bogati kakovost življenja», je šport sestavljen družbeni pojav. Niegovo mesto in vloga $v$ družbi sta najbolj neposredno odvisna od stopnje razvitosti družbene zavesti, od potencialnih vrednot športne aktivnosti in realnih družbenih odnosov do teh vrednot. Pomen športa danes je $\vee$ nekaterih pogledih skorajda nedoumljiv. Niegova ekonomska vrednost je neizračunljiva, njegova vrednost za človekovo fizično in duševno zdravje nepredstavljiva.

Iz sklepne ugotovitve analize, ki je bila narejena $\mathrm{z}$ namenom ugotavljanja učinkov NPŠ za desetletno obdobje od njegove uveljavitve ${ }^{2}$ (Kolar et al., 2010, str. 339) izhaja, da kazalniki rasti in razvoja slovenskega športa kažejo, da je šport v Sloveniji v zadnjem desetletju napredoval tako z vidika obsega športne dejavnosti in športno dejavnih, kakor tudi z vidika kakovosti doseženih športnih rezultatov $v$ mednarodnem prostoru. Stalno je naraščalo število vrhunskih športnikov. Vrhunski lahko postanejo le, če dosegajo oziroma so dosegli vrhunske, svetovno primerljive športne rezultate. Analiza kaže, da so se izbolišali pogoji za delo $v$ vrhunskem športu (materialna baza, športna infrastruktura, strokovni kadri, znanstveno raziskovalna dejavnost). Ugotovljene so bile pozitivne povezave med organiziranostjo športa oziroma izvajalci športa, sprejemanjem in izvajanjem sistemskih ukrepov, ki temeljiio na zagotavljanju finančnih virov (sofinanciranje športa) in razvojem vrhunskega športa ter njegovimi učinki na vrhunske športne dosežke.

Zelo pomembno področje športa za družbo, nacijo in posameznika je vrhunski šport. Je dejavnost, ki je predvsem zasebna dobrina, vendar je zaradi pozitivnih eksternalii na celotno družbo tudi javna dobrina, zato se financira iz javnih financ (Kolar, 2005, str. 43). Država in lokalne skupnosti izvajajo sistemske ukrepe na podlagi temeljnega pravnega akła za šport, Zakona o športu ${ }^{3}$ in temelinega strateškega dokumenta v športu, NPŠ. Z NPŠ je opredelieno uresničevanje javnega interesa na področju

1 Nacionalni program športa v Republiki Sloveniii, Uradni list RS, št. 24/2000, 31/2000 (v nadaljevanju: NPŠ 2000)

2 Za obdobje od leta 2000, ko je bil NPŠ v Državnem zboru Republike Slovenije sprejet, do izteka njegove veljavnosti leta 2010.

3 Zakon o športu, Uradni list RS, št. 22/98, 61/2006 (v nadaljevanju: Zspo) 
športa, z njim država soustvaria pogoje za razvoj športa. Med drugim z vsebinami ter s strokovnimi in razvojnimi nalogami določa način podpore tako uveljavljenim, vrhunskim športnikom, kot tudi mladim talentom. Država ima z ZSpo in NPŠ sprejete številne sistemske ukrepe za podporo slovenskim športnikom. Pa naj si gre za čas njihove aktivne športne poti, kot za čas po njihovi končani športni karieri. Vprašanje, ali je ta podpora zadostna, se vedno znova pojavlja, ko ti dosežejo odmevne mednarodne športne rezultate.

Namen prispevka je predstaviti pomen enega izmed podpornih ukrepov, ki jih je država sprejela za podporo slovenskemu vrhunskemu športu. Gre za zaposlovanje vrhunskih športnikov v slovenski državni upravi. Kriza oziroma slabšanje gospodarskih razmer, vse boli narekuje poseg $\vee$ zmanjševanje pravic zaposlenih $\vee$ državni upravi, $\vee$ dosledno izvajanje že pred leti sprejetega varčevalnega ukrepa vlade "minus 1 \%". Ker so tudi zaposleni vrhunski športniki v državni upravi javni uslužbenci, vse kaže, da se bo ukrep dotaknil tudi njih. Članek predstavlja pojmovanje vrhunskega športa in njegovo vrednotenje, pomen in namen zaposlovanja vrhunskih športnikov $v$ državni upravi, predstavlja pravne dileme $v$ zvezi $z$ dosedanjo prakso izvajanja sporazumov oziroma nemotenim izpolnjevanjem veljavnega sporazumoma, ter $s$ konkretnimi predlogi nakaže pot za izboljšanje stanja.

\section{Vrhunstvo $v$ športu}

Vrhunski šport je posebna oblika športne dejavnosti, s katero vrhunski športniki dosegajo športne rezultate, ki višajo meje zmožnega, dokazujejo zgornje meje človeških psihofizičnih sposobnosti. Pomeni eno najvišjih oblik človekove ustvarjalnosti na področju športa. Je najvišja stopnja tekmovalnega športa, za katerega je značilna težnja po doseganju najboljših športnih rezultatov $v$ posameznih panogah. Kolar in sodelavci (2007, str. 51) opredeljujejo vrhunski šport kot multiplikator in generator množičnih oblik športnega udejstvovanja (pasivnega in aktivnega), sredstvo za potrditev narodne identifikacije (prek vrhunskega športa narod dokaže, kaj zmore), promotor vseh oblik množičnega športa, sredstvo oglaševanja za industrijo in storitve, promotor države in sredstvo dokazovanja športnikov in vseh, ki z njimi delajo. Če smo v preteklosti za vrhunski šport trdili, da je $v$ bistvu igra, se zdaj zavedamo, da gre za trdo ustvarjalno delo, $v$ katerem se prepletajo osebni, narodni, gospodarski, politični in drugi interesi (Bednarik et al. v: Jurak, 2007, str. 39). Vrhunski 
šport je tudi področje, na katerem se lahko prek dosežkov na mednarodni ravni uresničujejo koristi države (npr. prepoznavnost). Z njim se potrjujejo družbeni sistemi in države ter posamezniki.

Vrhunski šport je $\vee$ Sloveniji dogovorno opredeljen $\vee 2$. členu ZSpo (1998, str. 7-8; NPŠ, 2000, str. 42) kot "priprava in tekmovanje športnikov, ki imajo po merilih Olimpijskega komiteja Slovenije (v nadaljevanju: OKS) za kategorizacijo športnikov $v$ Republiki Sloveniji status mednarodnega, svetovnega in perspektivnega razreda«.

"Če osvetlimo dogajanje z lučjo ekonomskih teorii, ugotovimo, da športni trening, kot produkcija, začne proces, $v$ športnem tekmovanju se vrši distribucija športnega rezultata in z gledanjem športnega dogodka se izvrši njegova poraba« (Dvoržak et al., 2001, str. 3). Športni dosežek torej ni cilj samo športnika. Po Globočniku (2008, str. 11) vrhunski športnik v športni karieri podredi treningom in seveda posledično končnemu cilju tekmovanjem za dosego vrhunskih športnih rezultatov, večji del svojega časa. V življenju vrhunskega športnika ni prostora (ali ge je zelo malo) za kakršnokoli drugo dejavnost, $v$ neenakem položaju so tudi pri razvoju poklicne kariere. Športniki preživijo večino leta na pripravah in $v$ tekmovalni sezoni na tekmovanjih. Za tekmovalca $v$ zimskem športu, denimo biatlonu, to pomeni povprečno letno odsotnost okoli $200 \mathrm{dni}$. Preostalih 165 dni pa poteka trening doma.

\section{Vrednotenje tekmovalne uspešnosti v slovenskem športu}

Vrednotenje tekmovalne uspešnosti v posameznih športnih panogah $v$ Sloveniji poteka na podlagi Kriterijev za kategorizacijo športnikov v Republiki Sloveniii (Kolar et al., 2007a, 2007b). Odbor za vrhunski šport (OVŠ) pri Olimpiijkem komiteju Slovenije - Združenju športnih zvez (OKS - ZŠZ) dvakrat letno objavi seznam vrhunskih športnikov, ki so si na podlagi doseženih rezultatov in $v$ skladu $z$ veljavnimi kriteriji pridobili status kategoriziranega športnika Republike Slovenije svetovnega, mednarodnega ali perspektivnega razreda ${ }^{4}$.

4 Pogoji, pravila in kriteriji za registriranje in kategoriziranje športnikov v Republiki Sloveniii (OKS - ZŠZ, zadnji tovrstni dokument št. 30303-2-14/9 z dne 11. 6. 2010; pogoji, pravila in kriteriji so bili od leta 1993 nekajkrat spremenjeni, vendar ne v tolikšni meri, da bi spremembe opazno vplivale na dinamiko večanja števila vrhunskih športnikov, kot je razvidna iz grafikona 1). 
Naziv "športnik perspektivnega razreda" pridobi športnik mladinec ali kadet (pod enakimi pogoji tudi mlajši član ali član) na osnovi uvrstitve na svetovnih in evropskih mladinskih prvenstvih, svetovnih ter evropskih rang lestvicah in doseženega svetovnega ali evropskega mladinskega rekorda ${ }^{5}$.

"Športnik mednarodnega razreda" je naziv, ki ga dobi športnik na osnovi uvrstitve na olimpijskih igrah (OI), svetovnih ali evropskih prvenstvih (SP, EP), svetovnih igrah, sredozemskih igrah, svetovnih pokalih, tekmovanjih za veliko nagrado, doseženega svetovnega ali evropskega rekorda $\vee$ neolimpijskih ${ }^{6}$ disciplinah, svetovnih in evropskih rang lestvicah, svetovnih in evropskih klubskih prvenstvih. Ta naziv dobi tudi športnik invalid na osnovi uvrstitve na paraolimpijskih igrah, olimpijskih igrah gluhih, svetovnih, evropskih prvenstvih ali za drug dosežek, opredelien $v$ kriteriijh.

\section{Grafikon 1: Kategorizirani vrhunski športniki v obdobju 1991-2010}

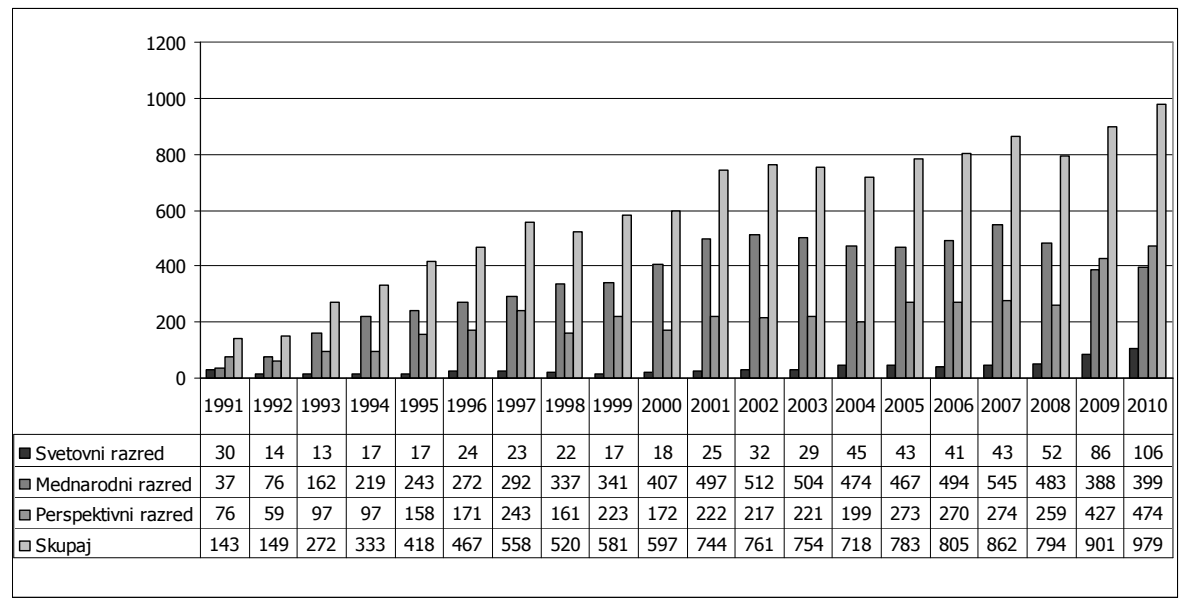

Vir: MŠŠ, OKS - ZŠZ (1999-2011)

Naziv "športnik svetovnega razreda" pridobi športnik na osnovi uvrstitve na OI, SP, za osvojeno medaljo na EP, svetovnih igrah, za končno uvrstitev $v$ svetovnem pokalu ali nekaterih drugih primerljivih tekmovanjih ter za dosežen svetovni ali evropski rekord. Ta naziv dobi tudi športnik invalid za osvojeno medaljo na paraolimpiijkih igrah in

5 Ali drug dosežek, če je to v kriterijih za posamezno športno panogo ali disciplino posebej opredeljeno.

6 Skladno s Pravili Olimpijskega komiteja Slovenije (OKS) delimo športne panoge in športne discipline $v$ "olimpijske" in "neolimpijske". Olimpiiske so tiste, ki so na rednem programu zimskih in letnih olimpijskih iger (OI). 
olimpijskih igrah gluhih. Status športnika svetovnega razreda traja štiri leta.

Število vrhunskih športnikov svetovnega, mednarodnega in perspektivnega razreda je, kot je razvidno iz grafikona 1, med leti 1991 in 2010 v Sloveniji neprestano in konstantno naraščalo. Niihovo število se je skoraj početverilo. Iz 143 je naraslo na 979, kar pomeni, da je bilo tolikšno število športnikov udeležencev velikih mednarodnih športnih prireditev ${ }^{7}$ kjer so dosegli vrhunski športni dosežek. To pomeni, da so naši vrhunski športniki $v$ vse večjem številu dosegali mednarodno primerljive rezultate (le tako so lahko bili razvrščeni, kategorizirani), ki so predstavljeni $\vee$ grafikonu 2. Prikazana je rast števila osvojenih medali slovenskih športnikov na OI, SP in EP.

\section{Grafikon 2: Osvojene medalje slovenskih vrhunskih športnikov v obdobju 1991-2010}

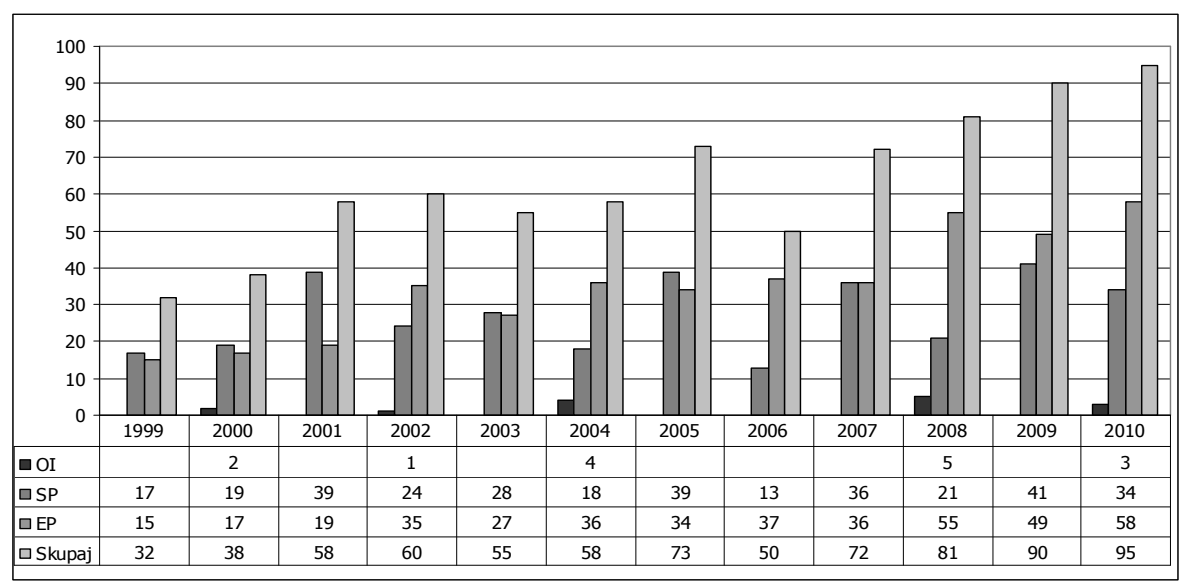

Vir: MŠš, OKS - ZŠZ (1999-2011)

Grafikon 2 kaže vzpon kakovosti slovenskega športa, k čemur so nedvomno prispevali tudi sistemski ukrepi, ki izhajajo iz SZpo in NPŠ, med njimi tudi zaposlovanje vrhunskih športnikov v organih državne uprave.

7 Pred podrobnejšim opisom navedenih kategorizacii po razredih je vredno predstaviti tudi velike mednarodne športne prireditve, na katerih se vrhunski rezultati lahko dosegajo in so merilo za vrednotenje in posledično kategorizacijo. Velike mednarodne športne prireditve po ZSpo (1998) so: Ol, sredozemske igre, univerziade, svetovna in evropska prvenstva (tudi mladinska), svetovni pokali in grand prix mitingi in turnirii.

110 Uprava, letnik IX, 2/2011 


\section{Sistemski ukrepi podpore države vrhunskemu športu}

Z ZSpo (1998), z vsebinami ter strokovnimi in razvojnimi nalogami NPŠ (2000) in drugimi predpisi je država za podporo športnikom, predvsem perspektivnim in vrhunskim športnikom, sprejela oziroma predpisala številne neposredne ali posredne ukrepe, namenjene tako uveljavljenim, vrhunskim športnikom, kot tudi mladim talentom. Aktualne pravice vrhunskih športnikov so (MŠŠ, 2009b):

- plačilo prispevkov za obvezno zdravstveno zavarovanje;

- plačilo prispevkov za nezgodno zavarovanje;

- plačilo prispevkov za starševsko varstvo;

- plačilo prispevkov za pokojninsko in invalidsko zavarovanje;

- sofinanciranje nadstandardnega zdravstvenega zavarovanja vrhunskih športnikov - tudi za vrhunske športnike mednarodnega in perspektivnega razreda;

- plačilo prehodnih in obdobnih zdravstvenih pregledov športnikom, ki nastopajo na uradnih tekmovanjih nacionalnih panožnih športnih zvez;

- sofinanciranje priprav in nastopov mlajših, mladinskih in članskih reprezentanc na EP, SP, OI in sredozemskih igrah, mladinskih športnih igrah Alpe Jadran, evropskem olimpijskem festivalu mladih in mladinskih igrah treh dežel;

- sofinanciranje štipendij nadarjenih športnikov dijakov in študentov;

- zagotavljanje zdravstvenega varstva športnikov:

- zagotavlja se posebna organizacijska oblika izobraževanja mladih športnikov; usmerjenih $v$ doseganje vrhunskih rezultatov, s čimer jim je omogočeno ob športnih uspehih tudi uspešno izobraževanje (športni oddelki v gimnazijah);

- prilagajanje šolskih obveznosti športnikov učencev, dijakov in študentov;

- sofinanciranje plač trenerjev $v$ panožnih športnih šolah (država zagotavlia trenutno 126 trenerjem 80 \% plače);

- sofinanciranje meritev ugotavljanja in spremljanja ravni pripravljenosti športnikov na Inštitutu za šport Fakultete za šport; 
- celotna športna kariera se lahko športniku tudi šeje kot delovna doba;

- sofinanciranje športne infrastrukture;

- zagotavljanje izjemne pokojnine osebam, ki imajo posebne zasluge na področju športa (osvojena medalja na OI, SP ali EP, ali dosežen svetovni rekord $v$ članski konkurenci, ob izpolnitvi pogojev za starostno pokojnino);

- zaposlovanje vrhunskih športnikov v državni upravi.

Skladno s sklepom ministra pristojnega za šport ${ }^{8}$ (MŠŠ, 2009a) se za urejanje statusa vrhunskim športnikom po končani športni karieri zagotavlia:

- brezplačne programe usposabljanja in brezplačne licenčne seminarje za vrhunske športnike, ki se lahko za strokovno (trenersko in drugo) delo $v$ športnih organizacijah po športni karieri brezplačno usposobijo in brezplačno pridobijo licenco za opravljanje strokovnega dela $v$ športu. $V$ ta namen se zagotavljajo sredstva iz Evropskega socialnega sklada (ESS). II. stopnja usposobljenosti je tudi pogoi za pridobitev statusa zasebnega športnega delavca, in s tem je omogočena skrb za socialno varnost (zdravstveno, pokojninsko, invalidsko zavarovanje);

- plačilo šolnin vrhunskim športnikom - z vsakoletnim razpisom za izobraževanje odraslih MŠš od leta 2009 v celoti sofinancira izobraževanje vrhunskih športnikov, ki po 25. letu starosti z zaključenim letnikom ali izobraževanjem znotrai srednješolskega izobraževanja pridobijo stopnjo izobrazbe. Po letu 2011 se bo vrhunskim športnikom financiralo tudi šolnine za pridobitev višješolske izobrazbe;

- finančna nagrada vrhunskim športnikom in njihovim trenerjem za športne dosežke (medalje na EP, SP in OI) se izplačuje iz državnega proračuna neposredno športnikom (nagrada ne gre $v$ dohodninsko osnovo).

$\checkmark$ praksi se nemalokrat ugotavlja, da se športniki podpore in "bonitet", ki jim jih država daje in zagotavlja, sploh ne zavedajo.

8 Ukrepi za urejanje statusa vrhunskih športnikov po končani športni karieri (MŠš, 2009).

112 Uprava, letnik IX, 2/2011 


\section{Analiza zaposlovanja vrhunskih športnikov in trenerjev $v$ državni upravi}

$\checkmark$ tem prisperku se bomo omejili zgolj na sistemski ukrep "zaposlovanje vrhunskih športnikov $v$ državni upravi", ki je še posebej zanimiv $v$ luči varčevalnih ukrepov, ki jih mora država sprejeti $v$ krizni gospodarski in ekonomski situaciij.

$\checkmark$ Sloveniji se je zaposlovanje vrhunskih športnikov pojavilo po osamosvojitvi. Prvi vrhunski športniki so bili zaposleni v sredini leta 1991. Takrat je bilo na podlagi sklepa vlade zaposlenih šest športnikov $v$ športni enoti takratne teritorialne obrambe. Pozneje je športna enota postala sestavni del vojaške policije v slovenski vojski. Februarja 1993 so zaposlili prve vrhunske športnike $v$ slovenski policiji, kar se šteje za prve zaposlitve vrhunskih športnikov $v$ državni upravi. $V$ carini se $v$ tistih letih vrhunski športniki še niso zaposlovali. Vse te zaposlitve so bile izvedene predvsem na podlagi dogovorov med panožnimi športnimi zvezami in ministrstvi brez prave pravne podlage.

Ob spoznanju, da je lahko vrhunski športnik uspešen le, če ima zagotovljene ustrezne materialne in druge pogoje ${ }^{9}$ za nemoteno treniranje in tekmovanje ter zagotovljeno socialno in ekonomsko varnost, je država $\checkmark$ vrhunskih športnikih prepoznala tudi lastni interes in pričakovane splošne učinke njihovega zaposlovanja $v$ državnih organih (MŠŠ et al., 2007, str. 1):

- promocija države s športom (ali preko njega); športniki k prepoznavnosti države pripomorejo z vrhunskimi dosežki (naslov olimpiiskega ali svetovnega prvaka),

- dvigovanje ugleda države,

- reševanje programskih zasnov.

Slovenija je sledila zgledom večine držav Evropske unije. Maja leta 1996 je bil podpisan prvi Sporazumom o zaposlovanju vrhunskih športnikov in trenerjev $v$ Ministrstvu za obrambo - Slovenski vojski, Ministrstvu za notranje zadeve - Policiji in Ministrstvu za finance - Carinski upravi ( $v$ nadaljevanju: sporazum). Sporazum so podpisali ministri resorjev, ki zaposlujejo športnike in trenerje, minister za šolstvo in šport ter predsednik OKS. V sporazumu je bilo predvideno, da se bo do leta 2000

9 Mednje sodijo: organizacijska struktura športnega okolja, športna infrastruktura, vrhunsko usposoblieni strokovni kadri (trenerii), interdisciplinarna strokovna podpora ipd. 
v državni upravi postopoma zaposlilo 200 vrhunskih športnikov. Ob podpisu sporazuma je bilo $v$ Sloveniji kategoriziranih približno 450 vrhunskih športnikov (glei grafikon 1). V sporazumu so bili zapisani tudi predvideni učinki za šport (MŠŠ et al., 2007, str. 2):

- podpora vrhunskim športnikom in trenerjem, ki deluje $v$ tržno manj zanimivih športih; športniki in trenerii se lahko $v$ celoti posvetijo treningom in tekmovanjem,

- izboljšanje splošnih pogojev dela v športu,

- dvig rezultatov in promocija športa.

Svoj interes pri tem so prepoznale tudi državne institucije, ki športnike zaposlujejo (MŠŠ et al., 2007, str. 2):

- promocija državnih institucij na SP, mednarodnih tekmovanjih in na SP teh institucij; policijsko in vojaško SP $v$ letnih in zimskih športih ter svetovne igre carinikov,

- večja prepoznavnost institucii, $\vee$ katerih so zaposleni vrhunski športniki in trenerii (prisotnost $v$ medijih),

- povečana delovna usposobljenost posameznih institucii oziroma njihovih enot (nasveti in pomoč vrhunskih športnikov pri pripravi programov usposabljanja),

- možnost, da se delavci teh institucij identificirajo z vrhunskimi športniki, promocija športa in njegovih učinkov $v$ posameznih organih,

- višja raven športne kulture $v$ organih oziroma institucijah, kjer je dobra psihofizična priprava eden izmed osnovnih pogojev uspešnega dela.

Prvo merilo za zaposlovanje vrhunskih športnikov in trenerjev $v$ državni upravi je bilo v skladu s sporazumom merilo športne kakovosti, na podlagi katerega nastaja prednostna lista za zaposlovanje, ki jo pripravlja OKS. Pri tem je glavni kriterij kategorizacija vrhunskih športnikov na podlagi mednarodno primerljivih športnih rezultatov posameznega športnika. Drugo je merilo prednosti športne panoge, tretje pa merilo posebnih potreb ministrstva.

Splošni pogoii za zaposlitev športnika, določeni v sporazumu (MŠŠ et al., 2007, str. 4-5), so:

114 Uprava, letnik IX, 2/2011 
- kandidat mora imeti izpolnjene pogoje za pridobitev statusa kategoriziranega športnika, olimpiijkega, svetovnega, mednarodnega ali perspektivnega razreda,

- kandidat mora imeti končano najmani srednjo izobrazbo,

- pri kandidatu se upoštevajo doseženi rezultati na SP in EP v zadnjih dveh sezonah.

Splošni pogoji za trenerje, ki lahko kandidirajo za zaposlitev v državni upravi (MŠŠ et al., 2007, str. 4), pa so:

- kandidat mora imeti ustrezno strokovno usposobljenost in izdano licenco,

- prednostno se upoštevajo kandidati, ki so trenerii državnih reprezentanc, oz. da imajo pod svojim okriljem več kategoriziranih športnikov, ki imajo status svetovnega, mednarodnega ali perspektivnega razreda.

\section{Grafikon 3: Število zaposlenih športnikov po sporazumu v letih 1998-2006}

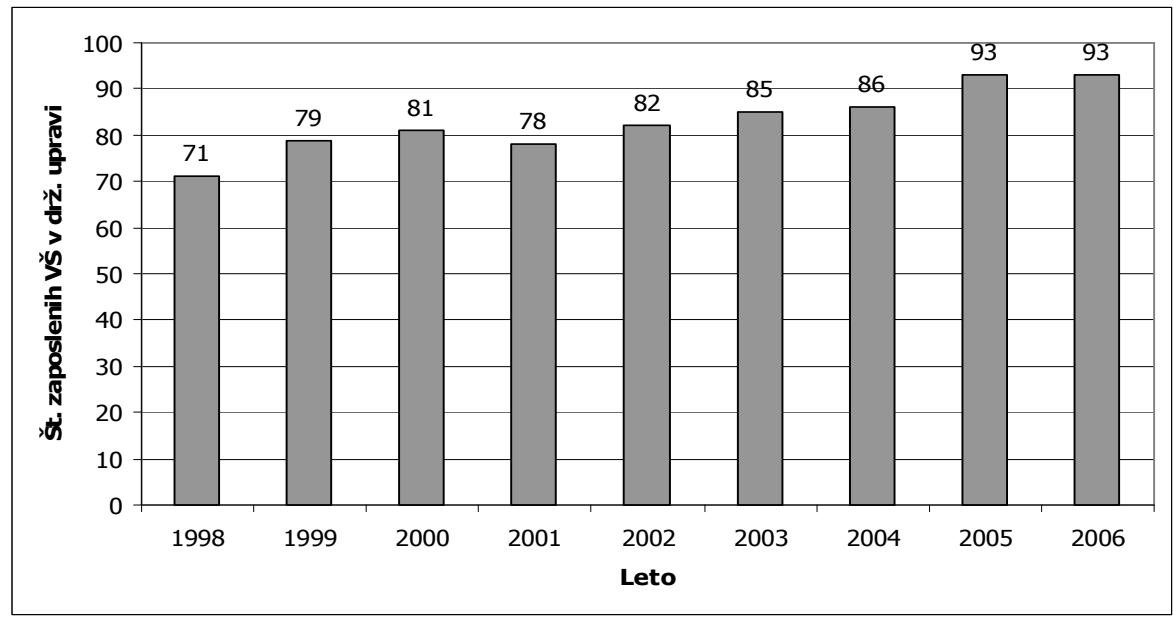

Vir: MŠš, OKS - ZŠZ (2011)

Grafikon 3 prikazuje gibanje števila vrhunskih športnikov zaposlenih v državni upravi $v$ obdobju od podpisanega prvega sporazuma $\circ$ zaposlovanju leta 1996 do leta 2007. Kljub temu, da se je slovenski vrhunski šport izredno razmahnil, tako da se je za več kot dvakrat povečalo število vrhunskih športnikov ${ }^{10}$ (leta 1996 jih je bilo 467, leta

10 Takšno povečanje števila vrhunskih športnikov je lahko temeljilo ne doseganju svetovno primerljivih športnih rezultatov ter s tem izpolnjevanjem pogojev navedenih v poglavju 3. 
2007862 - glej grafikon 1), zaposlovanje že $v$ teh letih ni sledilo sporazumu. Do leta 2000 so jih ministrstva od predvidenih 200 zaposlila le 81 (grafikon 3).

Zato je bil leta 2006 usklajen in pripravljen, leta 2007 pa podpisan, nov Sporazum o zaposlovanju vrhunskih športnikov in trenerjev v MORS Slovenski vojski, MNZ - Policiii in MF - Carinski upravi. Poleg resornih ministrov ministrstev "zaposlovalcev" ga je podpisal tudi minister za javno upravo. Ministri so se ponovno obvezali, da bodo $v$ prvem sporazumu (1996) določeno število vrhunskih športnikov in trenerjev, zaposlenih v državni upravi (200), postopoma uresničili do leta 2015. Ob podpisu novega sporazuma je državna uprava zaposlovala 98 športnikov.

Posledično je bil leta 2008 dopolnjen Zakon o javnih uslužbencih (ZJU, Ur. lisł RS, št. 69/2008), kjer je bila 1. odstavku 68. členu" dodana 7. točka, ki zaradi podpore in promocije vrhunskega športa omogoča zaposlovanje vrhunskih športnikov ali trenerjev za določen čas. 69. členu (trajanje delovnega razmerja za določen čas) je bila dodan 7. odstavek, ki določa sklenitev delovnega razmerja za eno leto z možnostjo podaljšanja, pri čemer mora predstojnik organa, ki športnika ali trenerja zaposluje, preveriti izpolnjevanje pogojev (predvsem statusa vrhunskega športnika) za zaposlitev oziroma njeno podaljšanje. S tem so postali vrhunski športniki in trenerji, zaposleni $v$ javni upravi, javni uslužbenci $z$ vsemi pravicami in obveznostmi.

Iz grafikona 4 je razvidno gibanje zaposlovanja športnikov in trenerjev v državni upravi od leta 1996, ko je bil podpisan prvi sporazum, preko leta 2000 do leta 2007, ko je bil sporazum prenovlien, in trenutno stanje (leto 2011) zaposlenih športnikov in trenerjev. Veljavni sporazum predvideva, da se bo v skladu z novimi možnostmi za zaposlitev do leta 2010 povečalo število zaposlenih športnikov v slovenski vojski za najmani 44, torej na 100. Kot prikazuje grafikon 4, je bilo konec leta 2009 v vojski dejansko zaposlenih 81 športnikov, $v$ vseh treh resorjih, ki zaposlujejo, skupai 126, v začetku leta 2011 pa 116.

Sporazum iz leta 2007 poleg meril za zaposlovanje vrhunskih športnikov in trenerjev $v$ državni upravi, ki jih povzema po sporazumu iz leta 1996, opredeljuje tudi obveznosti teh športnikov in trenerjev (npr. da morajo nastopati na mednarodnih policijskih ali vojaških prvenstvih

11 IX. Poglavje - Delovno razmerje za določen čas.

116 Uprava, letnik IX, 2/2011 
z identifikacijo in simboli ministrstev oz. organov, za katere tekmujejo, da morajo sodelovati na promocijskih, propagandnih, protokolarnih in drugih prireditvah, ki jih organizirajo ministrstva, da morajo pomagati pri usposabljanju profesionalnih delavcev, skrbeti za ohranjanje osebne športne pripravljenosti...) in niihove pravice (pravica do ustrezne tekmovalne opreme, do nemotenega treninga, do nastopanja za klub in panožno zvezo, do usposabljanja in izpopolnjevanja ...).

\section{Grafikon 4: Gibanje zaposlovanja vrhunskih športnikov v državni upravi}

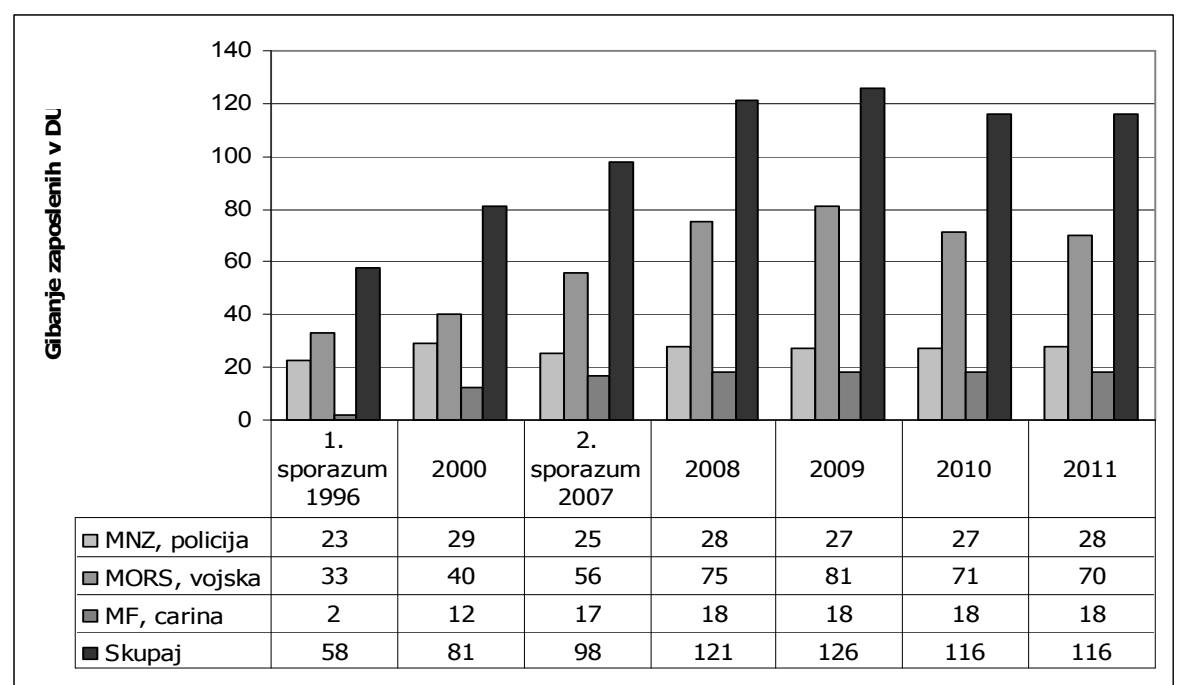

Vir: MŠš, OKS - ZŠZ (2011)

Glede na gospodarske razmere v državi v tem času, se je koordinacijsko telo ( $\mathrm{v}$ nadaljevanju: koordinacija) za zaposlovanje športnikov in trenerjev ${ }^{12}$, ki je zadolženo za predlaganje športnikov, ki naj bi se zaposlili $v$ državni upravi, glede na odstopanje dogovorjenega zaposlovanja (predvsem Ministrstva za obrambo, v nadaljevanju: MORS), veliko ukvarjala $\mathrm{z}$ vprašanjem oziroma zahtevo po zmanjševanju zaposlenih športnikov in trenerjev $v$ državni upravi. Pri tem je koordinacija iskala tudi rešitve, kako zagotoviti, da število zaposlenih športnikov in trenerjev ne bi bilo tako odvisno od gibanja zaposlenih $v$ državni upravi. Na pobudo Ministrstva za šolstvo in šport (MŠŠ) je predlagala, da se preveri možnost ločenega prikazovanja delovnih mest za zaposlene

12 Koordinacija za zaposlovanje vrhunskih športnikov in trenerjev je zadolžena za pripravo predlogov za zaposlitev športnikov in trenerjev $v$ državni upravi in za pripravo predlogov za prenehanje delovnega razmerja. Sestavljajo jo po en predstavnik ministrstev, ki zaposlujejo športnike in trenerie, predstavnik OKS ter predstavnik MŠš, ki koordinacijo tudi vodi. 


\section{Zaposlovanje vrhunskih športnikov v javni upravi na preizkušnii}

športnike $v$ okviru kadrovskega načrta vlade ( $v$ nadaljevanju: KNV), in to ji je uspelo. Pri pripravi predloga skupnega kadrovskega načrta MJU za leti 2011 in 2012 je bil ta predlog že upoštevan.

Hkrati se je, tako pri delu koordinacije, kakor tudi pri samem zaposlovanju športnikov in trenerjev, odprlo nekaj vprašanj, povezanih s kriteriji ${ }^{13}$ za zaposlovanje, kakor jih opredeljuje sporazum o zaposlovanju, in o statusu prednostne liste za zaposlovanje športnikov, ki jo oblikuje OKS. Koordinacija je ugotovila, da bi bilo treba $\vee$ razmerah, ko imajo resorii, ki zaposlujejo, včasih drugačna pričakovanja in zahteve kot OKS (ki si zlasti prizadeva, da dobijo zaposlitev športniki z vrhunskimi rezultati, ki so potencialni kandidati za olimpijade), preveriti obstoječe kriterije $v$ sporazumu.

Praksa je pokazala (pa tudi grafikon 4 tako kaže), da novi sporazum o zaposlovanju iz leta 2007 ni zagotovil pogojev, da bi število zaposlenih športnikov in trenerjev vsako leto ustrezno naraščalo. Zaradi zmanjševanja števila zaposlenih $v$ državni upravi je bilo ogroženo uresničevanje sporazuma. Zato je bila ustanovliena medresorska delovna skupina, katere naloga je bila proučiti stanje in najti take rešitve, ki naj bi zagotovile čim bolj nemoteno uresničevanje sporazuma, s čimer naj bi bili vrhunskemu športu in športnikom zagotovljeni ustrezni pogoji za njihovo treniranje in nastope. To je tudi $v$ skladu z javnim mnenjem, ki je izrazito naklonjeno vrhunskemu športu in šampionom.

Medresorska delovna skupina je ugotovila, da je za povečanje števila zaposlenih športnikov $v$ državni upravi, $v$ skladu s sklepom Vlade Republike Slovenije, treba:

13 Merilo športne kakovosti (temelji na doseženih mednarodno primerljivih športnih rezultatih, ki jih razvrščajo kriteriji za kategorizacijo športnikov v Republiki Sloveniii), merilo prednostne športne panoge a) športne panoge, ki so na programu nacionalnih in mednarodnih športnih iger posameznih ministrstev; b) športne panoge, ki so v ministrstvih zajete kot redno usposabljanje; c) vsi drugii individualni športi, merila posameznih potreb ministrstva (pri tem so še posebej pomembni določeni športi oziroma športna znanja. Ker tako zaposleni športniki lahko pomembno izboljšajo delovno usposobljenost posamezne organizacijske enote ministrstva, se lahko ministrstvo odloči, da zaposli določeno število športnikov ne glede na merilo športne kakovosti. Zaposlitev po tem merilu je treba vedno ustrezno pisno utemeljiti), merilo za zaposlovanje trenerjev (na predlog NPŠZ OKS predlaga koordinaciii zaposlitev trenerja državnih reprezentanc, in sicer praviloma $\vee$ primeru, ko so $v$ določenem ministrstvu zaposleni najmani trije športniki iz iste športne panoge).

118 Uprava, letnik IX, 2/2011 


\section{Darko Repenšek

- z VKN za leti 2011 in 2012 na ministrstvih zagotoviti kvote delovnih mest za zaposlitev 127 športnikov,

- $v$ proračunu zagotoviti potrebna finančna sredstva, kar na letni ravni za dodatnih 11 zaposlitev znaša 160.000 evrov,

- spremeniti Zakon o javnih uslužbencih ${ }^{14}$ ( $v$ nadaljevanju: ZJU), na podlagi katerega bo mogoče pripraviti ustrezen podzakonski akt (po možnosti vladne uredbe) o zaposlovanju vrhunskih športnikov in trenerjev $v$ državni upravi, ki naj bi nadomestil sporazum $\mathrm{O}$ zaposlovanju in zagotovil trdnejši dolgoročni pravni okvir za zaposlovanje vrhunskih športnikov in trenerjev $v$ državni upravi.

$\bigcirc$ kvotah za posamezna ministrstva, ki zaposlujejo športnike in trenerje, se delovni skupini ni uspelo uskladiti.

Zaradi pritiskov javnosti po izjemnih uspehih slovenskih športnikov na velikih mednarodnih športnih prireditvah (predvsem OI v Pekingu 2008) in po posredovanju predsednika države je bil junija 2009 pripravljen aneks k sporazumu o zaposlovanju vrhunskih športnikov in trenerjev iz leta 2007, ki so ga podpisali vsi pristojni ministri, razen ministrice, pristojne za obrambo ${ }^{15}$. Aneks vsebuje določilo, da se lahko vrhunskemu športniku svetovnega razreda, zaposlenemu $v$ državni upravi, $v$ skladu s tem sporazumom, pogodba o zaposlitvi podaljša še za dve leti po končani športni karieri (MŠŠ et al., 2009). To je bilo storjeno zato, da bi na ta način vrhunskim športnikom, zaposlenim $v$ državni upravi, po končani športni karieri omogočili primeren prehod v nov način življenja, ki naj bi vseboval tudi strokovno usposabljanje za lažje iskanje zaposlitve ${ }^{16}$. MJU,

14 Zakon o javnih uslužbencih, Uradni list RS, št. 63/2007, 69/2008 - UPB-3 (v nadaljevanju: ZJU).

$15 \mathrm{MORS}$ se je pri odklonitvi podpisa aneksa k sporazumu sklicevalo tudi na razlago MJU, ki je ocenilo, da aneks ni v skladu z ZJU. Vendar je bilo poudarjeno, da v vojski sicer nekaj časa ne bomo mogoče povečevati števila delovnih mesł za športnike, da pa se število zaposlenih športnikov ne bo zmanjševalo in januaria 2010 predlagalo pripravo novega besedila aneksa.

16 Vrhunska športna kariera zahteva od posameznika popolno osredotočenost in številni posamezniki športu prilagodijo vse druge dejavnosti, tudi šolanje in izobraževanje. Zaradi tega imajo športniki ob koncu kariere pogosto nižjo in slabšo izobrazbo kot njihovi vrstniki nešportniki. Sportniki so pogosto slabše pripravljeni na delo v poklicu. Zaradi neustrezne izobrazbe morajo bivši športniki sprejemati slabše plačana in manj zahtevna dela. Financiranje nadaljevanja izobraževanja še poveča športnikove eksistencialne težave $v$ pošportnem živlienju. Koncu športne kariere običajno sledi iskanje zaposlitve, pri čemer imajo športniki pogosto težave. Športniki, ki so med aktivno kariero prekinili in zanemarili

Uprava, letnik IX, 2/2011 119 


\section{Zaposlovanje vrhunskih športnikov v javni upravi na preizkušnii}

ki je aneks prvotno podpisalo, je kasneje od že podpisanega aneksa odstopilo z obrazložitvijo, da predlagano besedilo aneksa ni ustrezno, ker nima podlage $v$ ZJU, saj $s$ prenehanjem športne kariere vrhunskemu športniku preneha razlog, zaradi katerega je bila pogodba o zaposlitvi dejansko sklenjena ${ }^{17}$. Po ZJU (2008), ki je bil sprejet in uveljavljen po podpisu sporazuma o zaposlovanju leta 2007, so namreč športniki, zaposleni v državni upravi, postali javni uslužbenci.

Tako je bila izpostavljena pravna dilema glede statusa športnika po koncu športne kariere. $V$ kolikor vrhunski športnik po končanju športne kariere izgubi status vrhunskega športnika, potem ne izpolnjuje zakonskega pogoja za podaljšanje delovnega razmerja iz 7. odstavka 69. člena ZJU. Prevladalo je mnenje, da bi bilo to določbo treba spremeniti, če bi hoteli ohraniti sedanji aneks $k$ zaposlovanju, ki ga ministrica za obrambo ni podpisala prav zaradi navedene zakonske omejitve.

Koordinacija je s sklepom OKS naložila ustrezno rešitev vprašanja kategorizacije vrhunskih športnikov, da bodo ti lahko še dve leti po končani športni poti zakonito zaposleni $v$ državni upravi. Sklep je bil sprejet prav z namenom, da se zakonsko pokrije dodatna dveletna zaposlitev športnikov svetovnega razreda $v$ državni upravi po končani športni karieri.

Strokovni svet za šport Vlade Republike Slovenije je na predlog OKS maja 2010 sprejel sklep ${ }^{18}$, s katerim je spremenil določbe Pogojev, pravil

izobraževanje, v pošportnem življenju zaradi pomanjkliive izobrazbe veliko težje dobijo ustrezno zaposlitev (Globočnik, 2008, str. 33)

17 ZJU v prvem odstavku 68. člena primeroma določa, kdaj se lahko sklene pogodba za določen čas. V 7. točki prvega odstavka 68. člena je določeno, da se pogodba za določen čas lahko sklene $v$ primerih, ko gre za zaposlitev vrhunskega športnika ali trenerja zaradi podpore in promocije vrhunskega športa. Po določbi 7. točke 69. člena tega zakona se zgoraj navedeno delovno razmerje sklene za 1 leto z možnostjo podaljšanja. Pred podaljšanjem delovnega razmerja predstojnik preveri, ali so še izpolnjeni pogoji za zaposlitev, oziroma pogoji, ki jih organ, pristojen za vrhunski šport, določa za pridobitev statusa vrhunskega športnika. Če pogoji niso izpolnjeni, se delovno razmerje ne podaljša.

18 Pred točko 1.3.3.7 se doda nova točka 1.3.3.6.2: »lzredno podaljšanje statusa športnika svetovnega razreda" ter naslednje besedilo: "Status športnika svetovnega razreda, izjemoma tudi status športnika mednarodnega razreda, če je športnik v status športnika mednarodnega razreda prešel iz statusa športnika svetovnega razreda, se športniku, ki je prenehal nastopati na tekmovanjih uradnih tekmovalnih sistemov, lahko izredno podaljša do štiriindvajset (24) mesecev na podlagi pravočasno oddane vloge NPŠZ zaradi zagotavljanja statusnih pravic po končani karieri." 
in kriterijev za registriranje in kategoriziranje športnikov $v$ Republiki Sloveniji (OKS - ZŠZ, 2010) ter s tem zadostil določbi 7. odstavka 69. člena ZJU. Po tej spremembi pogojev je OKS v posameznih primerih, ko je športnik, zaposlen $v$ državni upravi, zaprosil za izredno podaljšanje statusa vrhunskega športnika, ta sklep že upošteval, kar pomeni, da so vrhunski športniki, zaposleni v državni upravi, tam lahko zaposleni še dve leti po tem, ko prenehajo tekmovati.

Pri analizi dokumentacije zaposlovanja vrhunskih športnikov v državni upravi od leta 1996 dalje (arhiv MŠŠ) in postopkov $v$ zvezi z iskanjem pravne podlage za zaposlovanje vrhunskih športnikov $v$ državni upravi je bilo ugotovljeno sledeče:

1. Praksa (tako pri nas kakor tudi v tujini) kaže, da je zaposlovanje športnikov $v$ vojski, policiji in carini dober ukrep države za podporo vrhunskemu športu, saj gre za področja, kjer je športnike mogoče ustrezno zaposliti ne le pri promociji resorjev, kjer so zaposleni, ampak tudi pri določenih opravilih, ki so specifična in tudi primerna za športnike, kar še zlasti velja za vojsko in policijo, delno pa tudi za carino.

2. Država Republika Slovenija ima z ZSpo in NPŠ sprejete številne sistemske ukrepe za podporo vrhunskemu športu in slovenskim vrhunskim športnikom, s čemer jim priznava delovanje $v$ javnem interesu in to področje tudi finančno podpira $z$ javnimi (proračunskimi) sredstvi.

3. Skladno s sporazumom so bili in so v državni upravi zaposleni le vrhunski športniki in trenerii individualnih športnih panog.

4. ZJU $\vee$ 68. in 69. členu vsebuje podlago za zaposlovanje vrhunskih športnikov in trenerjev $v$ državni upravi ( obrazložitveno določbo - promocija vrhunskega športa $v$ Republiki Sloveniii), zato predstavlja sporazum korektno pravno podlago za izvajanje ukrepa podpore države vrhunskemu športu, ne omogoča pa podaljšanja zaposlitve dve leti po prenehanju športnikove aktivne športne poti.

5. Sporazum o zaposlovanju vrhunskih športnikov v državni upravi iz leta 2007 je pravno-formalno veljaven in ga je treba smiselno izvajati. 
6. Interesi resornih ministrstev, ki skladno z veljavnim sporazumom zaposlujejo vrhunske športnike, ne sledijo interesom civilne športne sfere (OKS) oziroma vrhunskega športa.

7. MŠŠ in koordinaciijko telo vlagata velike napore $v$ zagotovitev stabilnega in zakonitega uresničevanja ukrepa podpore države vrhunskemu športu - sistema zaposlovanja vrhunskih športnikov v organih državne uprave, katerega uresničevanje naj ne bo odvisno od volje aktualne vlade oziroma aktualnih resornih ministrov.

8. MJU nima zadržka, da se kvota za zaposlitev športnikov in trenerjev $v$ državni upravi oblikuje ločeno, čeprav opozarja, da upoštevaje tako ZJU, kot tudi zakon, ki ureja javne finance in izvrševanje proračuna, kvote ni mogoče popolnoma izločiti iz VKN. Ta je $v$ skladu z zakonom podlaga za določanje obsega sredstev za plače, ki se zagotavlja $v$ proračunu Republike Slovenije, ta sredstva pa morajo biti načrtovana in zagotovljena na določenem programu in na določenih proračunskih postavkah proračunskega uporabnika (ministrstva). V skladu z 42. in 43. členom ZJU se namreč kadrovski načrt pripravlia upoštevaje proračunske možnosti, program dela in obseg nalog, predstojnik pa ga pripravlja hkrati ob pripravi proračuna.

9. MJU je pri pripravi predloga skupnega kadrovskega načrta za leti 2011 in 2012 sledilo predlogu MŠŠ, da se kvota za zaposlitev vrhunskih športnikov in trenerjev $v$ okviru skupnega kadrovskega načrta organov državne uprave oblikuje tako, da se prikaže in vodi ločeno v okviru kadrovskih načrtov posameznih ministrstev, v okviru katerih se športniki in trenerii zaposlujejo. Navedeni predlog pomeni, da se dovoljeno število zaposlitev športnikov in sredstva za ta namen planira $v$ okviru posameznega ministrstva, kjer so športniki zaposleni že sedaj. Kvota za njihovo zaposlitev pa bo določena posebej in bo razvidna $v$ okviru KNV.

10. Predlog MJU, da se kvota za zaposlitev vrhunskih športnikov in trenerjev centralizira $v$ okviru skupnega kadrovskega načrta organov državne uprave tako, da se prikaže in vodi ločeno $v$ okviru kadrovskega načrta MŠš, ki kot pristojno ministrstvo planira tudi sredstva za plače, je sprejemljiv. To pomeni, da je dovoljeno število zaposlitev športnikov in sredstva za ta namen načrtovano pri MŠŠ, ki naj bi skrbelo za realizacijo zaposlitev $v$

122 Uprava, letnik IX, 2/2011 
sodelovanju z ministrstvi, kjer so športniki zaposleni oziroma se zaposlujejo. Pri tem pa MŠŠ upravičeno izpostavlja vprašanje, ali ne bi bilo $v$ tem primeru najboli smotrno, da bi bili športniki zaposleni pri MŠŠ. Hkrati izpostavlja dilemo, kako in koliko bi ti športniki lahko opravljali posamezne dejavnosti v okviru MŠŠ, ki se vendarle po svoji dejavnosti bistveno razlikuje od resorjev, kjer so športniki zaposleni sedaj.

11. MJU meni, da bi vnaprej določeno možno število zaposlitev športnikov in trenerjev $v$ povezavi $z$ obsegom sredstev za plače omogočalo stabilen okvir za nadalinjo promocijo vrhunskega športa in ne bi bilo povezano $z$ aktualnimi oziroma nepredvidenimi dogodki $\vee$ resornih ministrstvih. Tako sprememba ZJU ni potrebna.

12. Glede na ravnanja MORS se zastavlja vprašanje, ali resorii, ki zaposlujejo športnike, znajo in vedno tudi zmorejo ustrezno izkoristiti sposobnosti in izkušnje zaposlenih športnikov. Resorii oziroma organi, ki zaposlujejo športnike, imajo tudi svoja domača in mednarodna športna tekmovanja, ki narekujejo zaposlovanje športnikov $v$ športih, ki so na programih teh tekmovanj, vendar je dosedanja praksa v zaposlovanju pokazala, da je mogoče te zahteve organov $v$ veliki meri upoštevati, saj koordinacija v sodelovanju z OKS poskuša najti ustrezne rešitve tako s stališča potreb športa kot tudi resorjev, ki zaposlujejo. So pa ta tekmovanja $v$ domačem kot mednarodnem merilu pomemben element promocije slovenske države in resorjev, kjer so športniki zaposleni. Vsega tega $v$ takem obsegu in na tak način MŠŠ (vezano na ugotovitev 10) verjetno ne bi moglo zagotavljati.

Iz navedenega je mogoče zaključiti, da je sedanja rešitev ustrezna in primerno normativno urejena, kar pa ne pomeni, da je ni treba $z$ dopolnitvami izboljšati. Predvsem v delu, ki bo omogočal izvedbo ukrepa po končanju športnikove aktivne športne kariere. Glede na gospodarskoekonomski položaj države in družbe lahko predvidevamo, da sporazum v dogovorjenem obdobju (do leta 2015) in predvidenem obsegu (200 zaposlenih vrhunskih športnikov) ne bo uresničen. 


\section{Zmanjševanje števila zaposlenih vrhunskih športnikov v slovenski vojski}

$\checkmark$ začetku leta 2010 so v MORS-u, skladno z usmeritvami vlade, pričeli z zmanjševanjem števila zaposlenih na ministrstvu, tudi športnikov $v$ vojski. Število zaposlenih športnikov in trenerjev so zmanjšali od 80, kolikor jih je bilo zaposlenih ob koncu leta 2009, na 70 zaposlenih. V kvoto pri njih zaposlenih športnikov so posegli z veliko večjim odstotkom zmanjšanja (11\%), kot ga je sicer vlada določila za zmanjševanje zaposlenih v državni upravi. Odločitev je šla v smer, da MORS zaposluje samo športnike iz športnih panog, v katerih so organizirana vojaška SP (CISM). S tem je bistveno odstopilo od določb sporazuma ${ }^{19}$.

Ravnanju MORS je sledil predlog MŠŠ ministrstvu za javno upravo $(M J U)^{20}$, da se v skupnem kadrovskem načrtu Vlade Republike Slovenije za leto 2010 pri organih državne uprave, ki zaposlujejo vrhunske športnike in trenerje, $v$ kadrovskem načrtu organa $v$ okviru skupne kvote vseh dovoljenih zaposlitev, ločeno prikazuje kvota zaposlitev, namenjena za zaposlovanje športnikov in trenerjev, in sicer: v MF - Carinski upravi 18 zaposlitev, v MNZ - Policiji 28 zaposlitev in v MORS - Slovenski vojski 80 zaposlitev, ter da vlada pri sprejemu skupnega kadrovskega načrta organov državne uprave za obdobje od leta 2011 do 2015, na podlagi sklenjenega sporazuma, ki pravi, da bodo podpisnice do leta 2015 zagotovile cilino število 200 zaposlenih športnikov in trenerjev, določi, da se skupna kvota delovnih mest za zaposlovanje vrhunskih športnikov in trenerjev $v$ organih, ki zaposlujejo vrhunske športnike, povečuje za 20 mest na leto, da bo do leta 2015 uresničen dogovorjeni cilj v sporazumu.

Kljub vsem prizadevanjem MŠŠ in krovne športne organizacije $v$ Republiki Sloveniij OKS, da bi se operativno sledilo veliavnemu sporazumu iz leta 2007, vse kaže, da je, oziroma bo, trend nadaljnjega zaposlovanja vrhunskih športnikov $v$ državni upravi pojenjal.

$19 \mathrm{Ni}$ sporno, da imajo v slovenski vojski športi, v katerih so organizirana vojaška svetovna prvenstva CISM, posebno mesto, ne morejo pa biti izključno merilo za zaposlovanje športnikov. Prvo merilo za zaposlovanje vrhunskih športnikov in trenerjev v državni upravi je prednostni vrstni red za zaposlovanje, ki ga pripravlja OKS in kjer je glavni kriterij kategorizacija vrhunskih športnikov na podlagi mednarodno primerliivih športnih rezultatov posameznega športnika.

20 Pismo ministra za šolstvo in šport resornim ministrom ministrstev, ki zaposlujejo, dne 20. 9. 2010 (MŠš, 2010).

124 Uprava, letnik IX, 2/2011 


\section{Predlogi za novo ureditev zaposlovanja vrhunskih športnikov in trenerjev $\mathbf{v}$ državni upravi}

Glede na ugotovljeno lahko predloge za izboljšanje stanja na področju zaposlovanja vrhunskih športnikov $v$ državni upravi, strnemo $v$ naslednjih točkah:

1. Za izvajanje zaposlovanja vrhunskih športnikov in trenerjev $v$ državni upravi je ZJU treba spremeniti oziroma dopolniti tako, da bo na njegovi pravni podlagi mogoče pripraviti ustrezen podzakonski predpis, ki bo nadomestil sporazum o zaposlovanju in zagotovil trdnejši dolgoročni pravni okvir za zaposlovanje vrhunskih športnikov in trenerjev v državni upravi. Dodati je treba določbo, ki bo omogočila ohranitev statusa zaposlenemu športniku dve leti po koncu njegove športne poti, oziroma, ko izgubi status vrhunskega športnika.

2. Če se ZJU ne spremeni in se obravnavano področje ne uredi s podzakonskim predpisom, je treba spremeniti, oziroma z aneksom dopolniti veljavni sporazum, ki naj določi tudi odstotek zaposlenih športnikov $v$ resorju, ki bodo zaposleni na podlagi merila posebnih potreb ministrstev.

3. Jasno je treba opredeliti oblikovanje kvote za zaposlitev vrhunskih športnikov in trenerjev $v$ okviru skupnega kadrovskega načrta organov državne uprave.

4. V državni upravi je treba omogočiti zaposlovanje tudi vrhunskim športnikom invalidom, saj so ti v vseh pravnih okviriih in aktih OKS statusno izenačeni z drugimi vrhunskimi športniki.

5. V državni upravi je treba omogočiti zaposlovanje tudi vrhunskim športnikom ekipnih športnih panog, saj so po veljavnem sporazumu $v$ neenakopravnem položaju $s$ športniki $v$ individualnih športnih panogah in disciplinah.

\section{Zaključek}

Vrhunski šport je med drugim sredstvo za potrditev narodne identifikacije, je promotor vseh oblik množičnega športa, promotor države in sredstvo dokazovanja športnikov in vseh, ki z njimi delajo. Predstavlja tudi področje, na katerem se lahko prek dosežkov na mednarodni ravni uresničujejo koristi države (npr. prepoznavnost). Z njim se potrjujejo 
družbeni sistemi in države ter posamezniki. Zato športni dosežek ni cili samo športnika.

Število vrhunskih športnikov, ki so dosegli mednarodno primerliive športne rezultate (medalje na olimpijskih igrah, svetovnih in evropskih prvenstvih), je $\vee$ Sloveniji $\vee$ času njene samostojnosti neprestano naraščalo. K temu nedvomno prispevajo tudi sistemski ukrepi države, ki je $\checkmark$ športu prepoznala javni interes. Pomemben ukrep države je zaposlovanje vrhunskih športnikov in trenerjev $v$ organih državne uprave, saj nedvomno drži dejstvo, da je vrhunski športnik lahko uspešen le, če ima zagotovljene ustrezne pogoje za nemoteno treniranje in tekmovanje ter zagotovljeno socialno in ekonomsko varnost. Država in državni organi so $\vee$ vrhunskih športnikih prepoznali tudi lastni interes in pričakovane splošne učinke njihovega zaposlovanja $v$ državnih organih, pri čemer je sledila zgledom večine držav Evropske unije.

Izvajanje ukrepa omogoča sporazum o zaposlovanju vrhunskih športnikov in trenerjev $v$ slovenski vojski, policiji in carini. Izvajanje sporazuma so od prvega podpisanega sporazuma leta 1996 naprej spremljale precejšnje težave, tudi pravne narave. Analiza je pokazala, da nobeden od doslej podpisanih sporazumov ni uresničil svoje zaveze, da bi število zaposlenih športnikov in trenerjev dogovorjeno naraščalo. Nasprotno. Predvsem zaradi ukrepov v MORS je zaznati trend upadanja števila zaposlenih vrhunskih športnikov v državni upravi. Glede na to, da javno mnenje $v$ zadnjem času državni upravi in javnemu sektorju ni naklonjeno, ko se glede na razmere $v$ gospodarstvu vse glasnejše zahteve po zmanjševanju števila zaposlenih $v$ vseh segmentih javne uprave, ne le državni upravi, lahko domnevamo, da se bo trend zaposlovanja vrhunskih športnikov $v$ državni upravi zmanjševal, kar gotovo ni dobro za vsestranske celostne učinke športa na družbo, zaradi katerih mu tudi politika pripisuje javno dobrino in je tako $v$ javnem interesu. Če želimo ostati "športna nacija" je treba sprejeti trdno politično zavezo in nadaljevati uresničevanje sporazuma, mu dati dodatne vsebine in pravno obličnost, ter zaposlovanju vrhunskih športnikov $v$ državnem sektorju zagotoviti stabilno ter dolgoročno pravno podlago $\vee$ ZJU. Da zaposlovanje ne bi bilo odvisno od volje aktualnih vlad oziroma ministrov ter spreminjajočih se ekonomskih razmer $v$ državi. Vrhunski športni dosežki so redki, so enkratni in se ustvariajo "na dolgi rok". 
Darko Repenšek vso svojo poklicno pot deluje v organih državne uprave. Od leta 2006 je sekretar na Ministrstvu za šolstvo in šport, kjer vodi Sektor za razvoj športa in investicije v Direktoratu za šport. V obdobju 1996-1998 je bil vključen $v$ avstrijsko-slovenski medvladni proces usposabljanja in izpopolnjevanja slovenskih višjih upravnih delavcev in je pridobil diplomo Avstrijske zvezne upravne akademije iz Dunaja in Fakultete za upravo Ljubliana. Je absolvent podiplomskega znanstvenega magistrskega študija Uprave na Fakulteti za upravo. Je zunanii sodelavec Fakultete za upravo in avtor številnih strokovnih prispevkov in priročnikov s področja vodenja $v$ javni upravi in področja športa ter soavtor dveh strokovnih kniig. 


\section{Zaposlovanje vrhunskih športnikov v javni upravi} na preizkušnji

\section{Literatura in viri}

- Bednarik, J., Dvoržak, J., Dobnikar, Ž., Kolenc, M. \& Pišot. R. (2001). Vrednotenje tekmovalnih športnih dosežkov in športnih panog v Sloveniji. Ljubljana: OKS - ZŠZ.

- Bednarik, J., Jurak, G., Bole Breznik, M., Pišot, R., Kolar. E. \& Kropej, V. L. (2007). Razlikovanje športnih organizacij z vidika večinsko opravljenega prostovolinega in profesionalnega dela. V Jurak (ur.). Nekateri kazalniki uspešnosti športnih organizacii v Sloveniji. Koper: Založba Annales, Univerza na Primorskem.

- Dvoržak, J., Dobnikar. Ž., Kolenc, M. \& Pišot, R., (2001). Vrednotenje tekmovalnih športnih dosežkov in športnih panog v Sloveniji. Ljubliana: OKS - ZŠZ.

- Globočnik, T. (2008). Zaposlovanje vrhunskih športnikov med in po karieri. Diplomska naloga. Ljubljana: Fakulteta za upravo.

Pridoblieno 13. 12. $2010 \mathrm{~s} \mathrm{http://www.fu.uni-}$ li.si/diplome/pdfs/diplomska/globocniktomas.pdf.

- Kolar, E. (2005). Model vrednotenja športnih panog v Republiki Sloveniii z vidika vrhunskega športnega rezultata. Doktorska disertacija. Ljubljana, Fakulteta za šport.

- Kolar, E., Bednarik, J., Kovač. M. \& Pišot, R. (2007a). Razvrščanje športnih panog z uporabo statističnih modelov. V Jurak, G. (ur.). Nekateri kazalniki uspešnosti športnih organizacij v Sloveniji, 69-113. Koper: Univerza na Primorskem, Znanstveno-raziskovalno središče Koper, Inštitut za kineziološke raziskave. Koper, Založba Annales.

- Kolar, E., Bednarik, J., Kovač. M. \& Pišot, R. (2007b). Objektivizacija vrednotenja športnih rezultatov in športnih panog. V Jurak, G. (ur.). Nekateri kazalniki uspešnosti športnih organizacij v Sloveniji, 47-68. Koper: Univerza na Primorskem, Znanstveno-raziskovalno središče Koper, Inštitut za kineziološke raziskave. Koper, Založba Annales.

- Kolar, E., Jurak, G. \& Kovač, M. (ur.) (2010). Analiza nacionalnega programa športa v Republiki Sloveniii 2000-2010. Ljubljana: Fakulteta za šport.

- MŠš et al. (2007). Sporazum o zaposlovanju vrhunskih športnikov v Ministrstvu za obrambo - Slovenski vojski, Ministrstvu za notranje zadevePoliciii, Ministrstvu za finance - Carinski upravi Republike Slovenije. Št. dokumenta: 110-100/2007-1, z dne 22. oktober 2007.

- MŠš. Sklepi Strokovnega sveta za šport Vlade Republike Slovenije.

- MŠš. (2010). Pismo ministra za šolstvo in šport. Št. dokumenta 121-072/00 dne 20. 9. 2010. 
- $\quad$ MŠŠ. Zaposlovanje vrhunskih športnikov v državni upravi. Arhivsko gradivo.

- $\quad$ MŠš. (2009a). Ukrepi za urejanje statusa vrhunskih športnikov po končani športni karieri.

- $\quad$ MŠŠ. (2009b). Aktualne sistemske rešitve na področju pravic vrhunskih športnikov. Dokument številka: 6710-5/2008, z dne 12. 5. 2009.

- MŠŠ et al. (2009). Aneks k Sporazumu o zaposlovanju vrhunskih športnikov $\checkmark$ Ministrstvu za obrambo - Slovenski vojski, Ministrstvu za notranje zadeve Policiji, Ministrstvu za finance - Carinski upravi Republike Slovenije.

- Nacionalni program športa v Republiki Sloveniji. Uradni list RS, št. 24/2000, $31 / 2000$.

- $\quad$ OKS - ZŠZ. (2010). Pogoii, pravila in kriteriji za registriranje in kategoriziranje športnikov v Republiki Sloveniji. Dokument št. 30303-214/9, z dne 11. 6. 2010.

- $\quad$ OKS - ZŠZ. (2011). Število zaposlenih športnikov po sporazumu v letih 1998-2006.

Pridobljeno 7. 5. $2011 \mathrm{~s} \mathrm{http://www.olympic.si/index.php?} \mathrm{id=139}$

- Zakon o športu. Uradni list RS, št. 22/1998, 61/2006.

- Zakon o javnih uslužbencih. Uradni list RS, št. 63/2007, 69/2008 - UPB-3. 
SUMMARY

\title{
EMPLOYMENT OF TOP LEVEL ATHLETES IN STATE ADMINISTRATION AT RISK
}

\author{
Key words: sport, top level athletes, employment of top level athletes in \\ public administration
}

Sport may be seen as a social, economic and media phenomenon. Sport affects all aspects of social life and involves individuals, narrow or broad social groups as well as various layers of population. A very important segment of sport for the society, for the nation and each individual is top level sport. Indicators of growth and development have shown that sport had made a progress in the last decade both in the extent of sporting activities and sports active citizens as well as from the point of view of quality of achieved sports results at the international level. The analysis of the fundamental strategic sports document in Slovenia the National Programme of Sport (NPS), being in power between 20002010, has shown that the working conditions in top level sport (material basis, sports infrastructure, expert staff, scientific research work) have been improved. Positive correlations were found between sports organisational structures and organisations implementing sport programmes, between adoption and implementation of system measures, based on the provision of financial resources (co-financing of sport) and top level sport development as well as with its impact on elite sport results. With the Law on Sport (ZSpo, 1998), with the contents and expert and development tasks of the NPS and other provisions the state introduced, in order to support athletes, in particular, perspective and top level athletes, a prescribed number of direct or indirect action measures for all, the affirmed top level athletes as well as for young talented athletes. The objective of the article is to present the importance of one of the supporting measures the state introduced in order to give support to Slovenian top level sport: the employment of top level athletes in the state administration.

Whereas we once ascertained that top level sport in fact is a game, we are now fully aware of the fact that it is a creative work where personal, national, economical, political and other interests are intertwined. Top level sport may also be considered as the area where through the achievements at the international level the state interest may 
be realised (e.g., visibility). Social systems, states and individuals are being confirmed through top level sport (1998, pp. 7-8, NPS 2000, p. 42) in terms of "preparations for athletes' competitions, who have according to the standards of the Olympic Committee of Slovenia (hereinafter OCS) for the categorisation of athletes in the Republic of Slovenia the status of international, world and perspective athlete«. Top level athletes subordinate a large part of his lifetime to their career in terms of training and consequently to their ultimate goal - to competitions leading to the top level sport results. There is no room in top athletes life (or there is very little room) for any other activity, and they are handicapped also in terms of development of their vocational career. The number of top level athletes of world, international and promising status has been in Slovenia steadily increasing between the years 1991 and 2011. Their number has increased almost four times. It grew from 143 to 979, which means that the same number of athletes actually participated at the big international sport events (Olympic Games, World and European Championships), where they achieved top level sport result. The latter is measured by the number of won medals the number of which also steadily grew between the years 1998-2010. Undoubtedly, also the system measures, based on the Law on Sport and NPS, contributed to those good results, among them also the employment of top level athletes in state administration.

Recognising that top level athletes may be successful only if their material and other conditions for undisturbed training and competitions are adequately provided and that their social security and their economic safety are ensured, the state has also recognised that top level athletes represent also the state interest and their employment in the state administration has many positive effects. In February 1993 first employments of top level athletes took place in the Slovenian Police, which are considered to be the first employments in the state administration. Slovenia followed through this example cases from the majority of EU member states. All employments have been put in place on the basis of agreements between sports federations and ministries with no particular legal basis. In May 1996 the first agreement on the elite athletes and trainers employment was signed at the Ministry of Defence Slovenian Army, the Ministry of Internal Affairs - Police and the Ministry of Finance - Customs Administration. Upon the signature of the agreement there were about 450 categorised top level athletes in Slovenia. The agreement envisaged that until the year 2000 there will be up to 200 top 
level athletes gradually employed in the state administration; however, the employment rate could not follow the provisions of the agreement. Till 2000 the ministries employed only 81 from the envisaged 200. As a result a new agreement was signed in 2007 , by which the respective ministers accepted the responsibility that they would gradually realize the agreed number of employed top level athletes and trainers (200) from the first contract (1996) by the year 2015. At the time of the signature of the first agreement the state administration employed 98 athletes. With the adoption of the Act on Civil Servants in 2008 also legal grounds were provided for the agreement for top level athletes employment in state administration, which in terms of support and promotion of top level sport provides part time employment of elite athletes and trainers (for one year with a possibility of extending for another term if basic condition is fulfilled, i.e., that they have the status of top level athlete or trainer). As a result, the employed elite athletes and coaches in state administration indeed became civil servants, and upon losing their status of top level athlete also their employment contract was terminated. In contrast to this provision (Law on Civil Servants) the Annex to the Agreement signed in May 2009 enshrines a provision that the employment contract in state administration can be extended for another two years for top level athletes of world status who finished their sporting careers. This way, elite athletes employed in state administration would be provided with an adequate transfer to their post-carer life cycle, which would include also vocational education and training in order to increase their employment opportunities.

Hence, a legal dilemma on the post career status of top level athletes was raised. Given that elite athletes lose their status of top level athlete (in principle they do), it means that they do not comply with the legal provisions for the extension of their employment in reference to paragraph 7 of article 69 of the Law on Civil Servants. There was a prevailing opinion that this provision should be altered in order to keep the annex on employment being in power at present, and which the Minister of Defence refused to sign exactly from the afore described legal limitations. In addition, the Ministry of Defence followed the directions of the Government concerning reduction of employed staff in state administration and in 2010 started to decrease the number of employees at their ministry, including athletes in the Slovenian Army. They reduced the number of employed athletes from 80 , which was the figure by the 
end of 2009, down to 70. That quota was in their case exceeded by $11 \%$ even more that determined by the Slovenian Government. The decision of the Ministry of Defence took the course of employing athletes only from those sports disciplines that are included in the organisation of the Military World Championships (CISM). Thus, the ministry departed significantly from the provisions of the agreement and therefore put its implementation at risk.

Despite all the endeavours of the Ministry of Education and Sport and the umbrella sports organisation in Slovenia, the OCS, to functionally follow the provisions of the agreement still in force from 2007, it seems that it already has, or it shortly will come true that the trends of top level athletes employment in state administration will be decreased.

In reference to the finding that the top level athletes employment in state administration has proven as a perfect measure of the state how to support elite sport in the Republic of Slovenia, we may summarise the proposals for the improvement in this area in the following points:

1. In order to implement the top level athletes and trainers employment in state administration it is necessary to amend the Law on Civil Servants in the way that it shall give legal basis to prepare adequate by-law replacing the existing agreement on employment and shall provide solid long term legal framework for the top level athletes and trainers employment in state administration. We should add the provision that would enable the maintenance of the status of the employed athletes two years after the conclusion of their sporting careers, and/or also in cases when they lose the status of top level athlete.

2. Should the Law on Civil Servant not be amended and the discussed matter not be settled through by-law provisions, it would seem necessary to change or to amend the existing agreement by an annex which should also determine the percentage of employed athletes in each government department to be employed also according to the regulations and the needs of each ministry.

3. The quotas for top level athletes and trainers employment in state administration should be clearly determined within the frame of common staff planning of state administration departments. 
4. Also disabled top level athletes should be given the opportunity of getting employment in state administration, since they are in all legal provisions and legal regulations of OCS equal in their status with the rest of elite athletes.

5. Also the elite athletes from team sports should be given the opportunity of employment in state administration as the existing agreement does not provide equal position to individual sports disciplines.

If our desire is to remain a "sporting nation" we would certainly need to make a firm political commitment to continue with the implementation of the agreement, and to give it a new content and a new legal frame, and to ensure for the employment of top level athletes in state sector a stable and long term platform in the Law on Civil Servants. The point is that employment should not be subject to good will of each government in position and of the ministers as well as of the changing economical situation in the country. Top level sport results are rare, they are unique and they are created "within long term" perspective.

134 Uprava, letnik IX, 2/2011 